\title{
Fluorescent Dissolved Organic Matter Dynamics in the Coastal Waters off the Central East Indian Coast (Bay of Bengal)
}

\author{
N.V.H.K. Chari, Nittala S. Sarma ${ }^{*}$, P. Sudarsana Rao, G. Chiranjeevulu, R. Kiran, K. N. Murty, \\ P. Venkatesh
}

Marine Chemistry Laboratory, School of Chemistry, Andhra University, India

Copyright $(\mathcal{C} 2016$ by authors, all rights reserved. Authors agree that this article remains permanently open access under the terms of the Creative Commons Attribution License 4.0 International License

\begin{abstract}
Excitation Emission Matrix (EEM) fluorescence spectra and hydrochemical parameters were measured monthly for a year in the western coastal waters of the Bay of Bengal in a shore normal transect up to the mid-shelf region. The parallel factor analysis of the EEM spectral data showed five fluorescent components, two protein (Tyrosine and Tryptophan protein-like, represented as B and T respectively) and three humic (UV humic, Marine humic and Visible humic-like represented as $\mathrm{A}, \mathrm{M}$ and $\mathrm{C}$ respectively). The $\mathrm{B}$ fluorophore was more enriched attributed to bacterial decay of photosynthetically produced organic matter and acted as proxy of primary production. The humic like fluorophores showed significant conservative behavior up to salinity $\sim 31$. During the pre-monsoon season, photo bleaching caused significant loss of $\mathrm{A}$ and $\mathrm{C}$ fluorescence making them deviate from conservative behavior but not from the linear distribution against chlorophyll a. The vertical profiles revealed systematic maxima for the humic fluorophores at depths during pre-monsoon and it is inferred that they owe their origin to phytoplankton.
\end{abstract}

Keywords Optical Properties, Excitation Emission Matrix Spectra, Parallel Factor Analysis, Bay of Bengal

\section{Introduction}

In the aquatic environments, dissolved organic matter (DOM) which is a complex and heterogeneous mixture of components is predominantly contributed by the degradation of plants, bacteria and zooplankton and plays an important role in the global carbon cycle [1]. In the coastal region, DOM of terrestrial origin contributed by the land humus predominates. Chromophoric dissolved organic matter (CDOM) is a significant fraction of DOM which absorbs radiation from visible to ultra violet (UV) wavelengths. Some fraction of CDOM exhibit fluorescence due to humic and protein like compounds, which is known as Fluorescent DOM (FDOM). The excitation emission matrix fluorescence spectroscopy combined with parallel factor analysis can be used to characterization of $\mathrm{CDOM}$ and its quantitative significance in DOM dynamics [2-4].

Many fluorescence studies have focused on surface waters of different water bodies e.g., ponds [5], water sheds [6], lakes [7], rivers [8], estuaries [9] and coastal surface waters [10-12] which are influenced by rivers [13] to elucidate their advantage to investigate the biogeochemical cycling of carbon, apart from other aspects. The few studies that have been carried out on FDOM dynamics in the coastal waters which are having no direct fresh water inputs from major rivers and for the water column to understand the influence of short term processes e.g., photic [14], and biogeochemical [15] processes and of water masses [16] to the ecosystem. However studies of CDOM dynamics in the coastal waters which are having no direct fresh water inputs from major rivers are scanty. In those regions surface as well as vertical distribution of optical properties may have significant trends due to in situ changes of CDOM. Towards this objective, monthly time series observations were done as a part of the SATellite Coastal and Oceanographic REsearch (SATCORE) project of Indian National Centre for Ocean Information Services (INCOIS) for a year in the coastal waters of Bay of Bengal (BOB) from near shore $(10 \mathrm{~m})$ to offshore $(100 \mathrm{~m})$ isobaths.

\section{Materials and Methods}

\subsection{Study Area}

The BOB is a unique and dynamic area which experiences seasonal changes in wind direction, immense fresh water input through rivers $\left(\begin{array}{lllll}1.6 & \mathrm{x} & 10^{12} \mathrm{~m}^{3} & \text { year }^{-1}\end{array}\right)$, excess precipitation over evaporation [17], and frequent atmospheric disturbances like depressions and cyclones [18]. River discharges from large rivers e.g., the Ganges- 
Brahmaputra river system, Godavari, Krishna, Mahanadi and Cauvery enter the Bay of Bengal in the western coastal region. The coastal city of Visakhapatnam is away from the nearest Godavari (south) and Mahanadi (north) estuaries by about $150 \mathrm{~km}$ and $250 \mathrm{~km}$ respectively. During the monsoon season (June - November) coinciding with the peak rainfall on the Indian subcontinent, these rivers experience floods. Due to the influence of the EICC(East Indian Coastal Current), the Godavari flood water can significantly dilute the Visakhapatnam coastal water at the peak of monsoon [19]. During the latter phase of SW monsoon, the same EICC brings water from the northern rivers particularly the $\mathrm{R}$. Ganges. The confluences of minor rivers Gosthani and the Sarada-Varaha which are towards north and south by about 15 and $40 \mathrm{~km}$ respectively from Visakhapatnam city have meagre impact on the Visakhapatnam coastal waters during the non-monsoon season; Hence little dilution accompanied with stable conditions of the water column are seen for this region.

\subsection{Sample Collection}

Sampling was done on board Coastal Research Vessels (CRV) Sagar Paschimi and Sagar Purvi owned by the Ministry of Earth Sciences, Govt. of India. When these vessels were not available, sampling was done on smaller mechanized vessels. The sampling stations are at $10 \mathrm{~m}, 20 \mathrm{~m}$, $30 \mathrm{~m}, 50 \mathrm{~m}, 75 \mathrm{~m}$ and $100 \mathrm{~m}$ isobaths which are away from the coast by $2-30 \mathrm{~km}$ (Fig. 1). Water samples were collected at surface at monthly intervals from October 2010 to October 2011 by using inner teflon coated 5 litre Niskin bottle. Water samples were additionally collected from the column at standard depths (surface, 10, 20, 30, 50, 75 and $100 \mathrm{~m}$ ) at the offshore station (100 $\mathrm{m}$ isobath) during the premonsoon (April 2011) and monsoon (September 2011). Salinity and temperature data were collected by using a portable conductivity, temperature and depth (CTD) profiler (SBE 19 plus; SeaBird Electronics, USA). Occasionally when the CTD was not available, the temperature was read from a calibrated clean thermometer $\left(0.1^{\circ} \mathrm{C}\right.$ precision $)$ suspended in the Niskin by opening its lid after subsampling for dissolved oxygen, and the salinity was determined in the shore laboratory by Mohr titration [20]. The depth of the photic zone was measured by dipping the sechi disc.

Water sample was collected for dissolved oxygen first without air bubbles, fixed with Winkler's reagents and the titrimetric estimation done. For the determination of Optical properties (absorbance and fluorescence), water samples were collected in amber colored glass bottles and immediately filtered through $0.22 \mu \mathrm{m}$ membrane Millipore filters, which were soaked with MilliQ water. One litre water was filtered separately onto GF/F Whatman filters for the estimation of chl a. These filters and the filtered samples for optical measurements (absorbance and fluorescence) were kept in a refrigerated container $\left(4-8^{\circ} \mathrm{C}\right)$ until analysis in the shore laboratory.

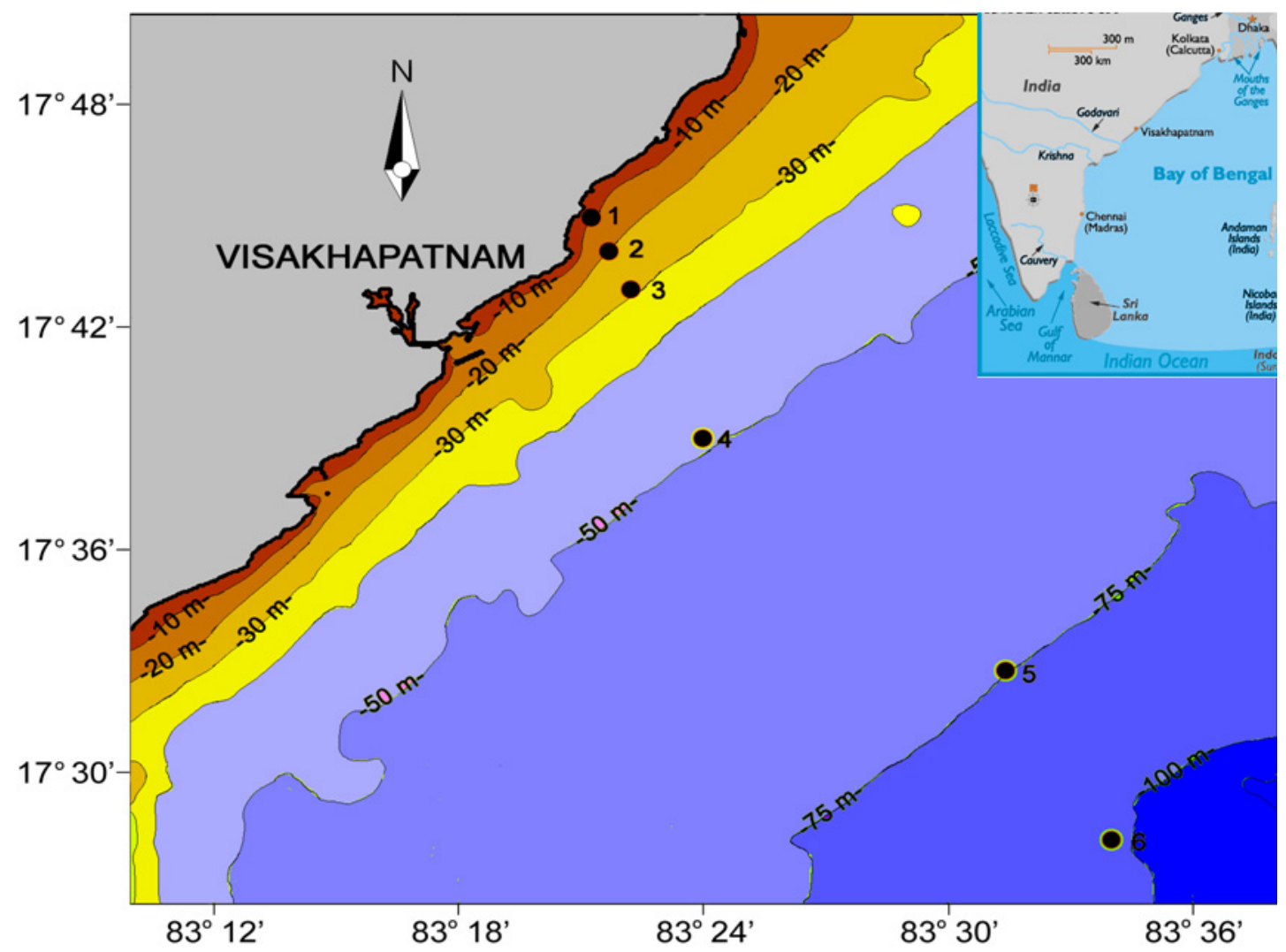

Figure 1. Station location map 


\subsection{Analytical Methods}

\subsubsection{Hydrochemical Parameters}

Dissolved oxygen was estimated by the modified Winkler's method [21]. For the determination of chl a, the filters containing the particulate matter were extracted in $90 \%$ acetone overnight at $4{ }^{\circ} \mathrm{C}$, and the absorption spectrum of the supernatant measured using Shimadzu 1800 double beam UV- Visible spectrophotometer. The concentration of chl a was calculated by using Jeffrey equations [22].

\subsubsection{Fluorescence}

The EEM spectra were taken on a Horiba JobinYvon Fluoromax-4 spectrofluorometer equipped with $150 \mathrm{~W}$ ozone-free xenon arc-lamp and R928P detector. The EEMs were collected by using excitation wavelengths between 250 $\mathrm{nm}$ and $402 \mathrm{~nm}$ at $4 \mathrm{~nm}$ interval and emission wavelengths from 290 to $550 \mathrm{~nm}$ at $2 \mathrm{~nm}$ interval. The instrument was set up to collect the corrected signal from sample $\left(\mathrm{S}_{1 \mathrm{C}}\right)$ normalized to the signal from reference detector $\left(\mathrm{R}_{1}\right)$, which is known as ratio $\left(\mathrm{S}_{1 \mathrm{C}} / \mathrm{R}_{1}\right)$ mode using $5 \mathrm{~nm}$ bandwidth on both excitation and emission monochromators with integration time $0.2 \mathrm{~s}$. The EEM spectra were then normalized with respect to the area under the Raman scatter peak (ex: $350 \mathrm{~nm}$, em: 381-426 nm; [23]). The Raman normalized MilliQ water EEM spectrum was subtracted from the EEM spectra of samples to remove the water Raman scattering. The resultant spectra are in Raman Units (RU). The RU is preferred as it is helpful for a global comparison $[2,23]$.

\subsubsection{PARAFAC Analysis}

PARAFAC analysis of the EEM dataset extracts the flurophores present in CDOM as components. The PARAFAC was done in MATLAB R2007a using the DOMFluor, which contains Nway toolbox ver 3.1 [24]. Determination of the optimum number of components was done by split half analysis and random initialization [24], as a part of the program. The PARAFAC analysis was applied to our dataset (80 samples) to obtain relative intensities (scores) of the components, from which absolute intensities were calculated $[2,25]$. Statistical analysis was done using Statsoft statistica 8 software.

\section{Results and Discussion}

\subsection{Hydrography}

Salinity at surface ranged from 21.17 to 33.98 in surface waters (Fig. 2). It showed lower values during October 2010 and attributed to the monsoon driven river discharges from northern rivers [26]. At the $100 \mathrm{~m}$ isobaths station where vertical profiling was done, salinity did not vary significantly between the monsoon season (range: 32.01 to 33.24) and the premonsoon (33.37 to 34.72) (Fig. 3a). However, the premonsoon - monsoon difference was that during the monsoon season a lower saline water occupied up to $30 \mathrm{~m}(32.11 \pm 0.10)$ while during the premonsoon, the salinity was constant in the entire water column $(33.50 \pm$ 0.09 ) due to mixing of the water column. Dissolved oxygen showed consistently high concentration $(228 \pm 11 \mu \mathrm{M})$ in the upper $50 \mathrm{~m}$ thick water column attributed to productivity aided by intense solar radiation and high transparency. Subsurface chlorophyll maxima occurred at $50 \mathrm{~m}$ depth during premonsoon season, agreeing with previous reports [27]. Premonsoon phytoplankton blooms have also been reported in this region [28]. While dissolved oxygen decreased from $50 \mathrm{~m}$ downwards in the premonsoon (Fig. $3 a)$, it decreased vertically starting from the surface itself during monsoon (Fig. 3b). This is attributed to bacterial decomposition of POM and DOM accompanying the freshwater input and in whose concentration the surface water is rich. The subsurface chlorophyll maxima during the monsoon season occurred at $30 \mathrm{~m}$ depth (Fig. $3 \mathrm{c}$ ) due to a low photic depth.

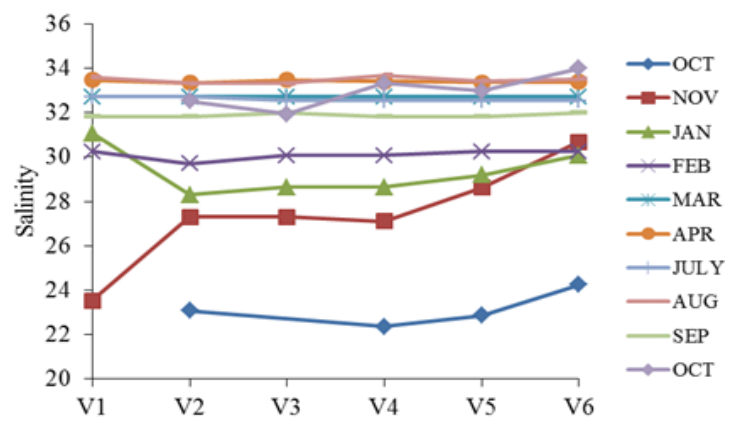

Figure 2. Spatio-temporal variation of salinity in surface waters
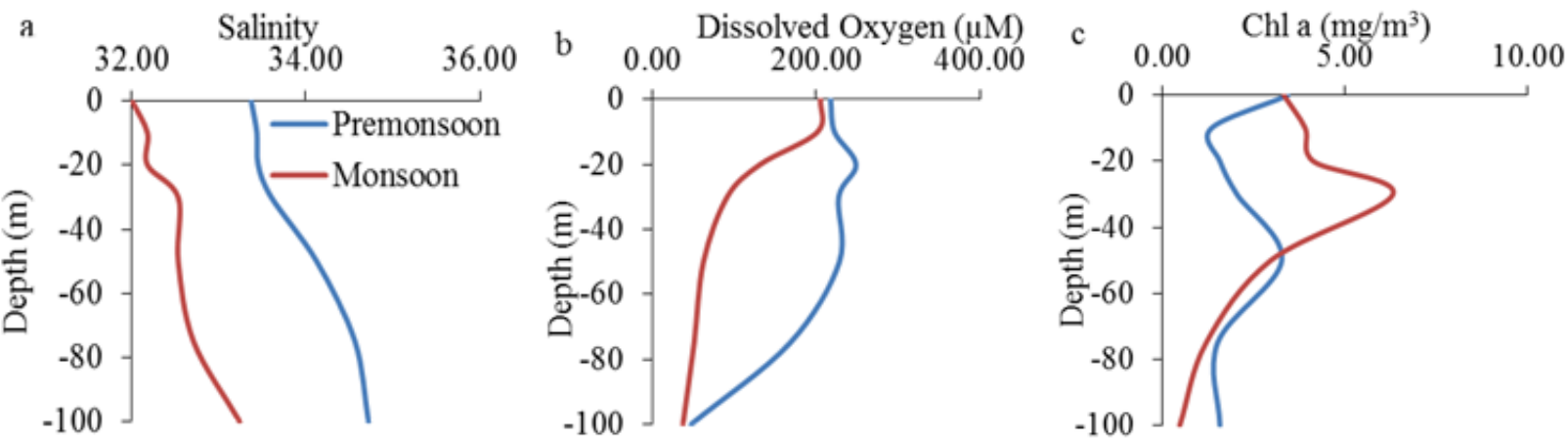

Figure 3. Vertical variations of hydrochemical parameters at $100 \mathrm{~m}$ isobaths during premonsoon and post monsoon a) salinity, b) Dissolved Oxygen and c) Chlorophyll a 

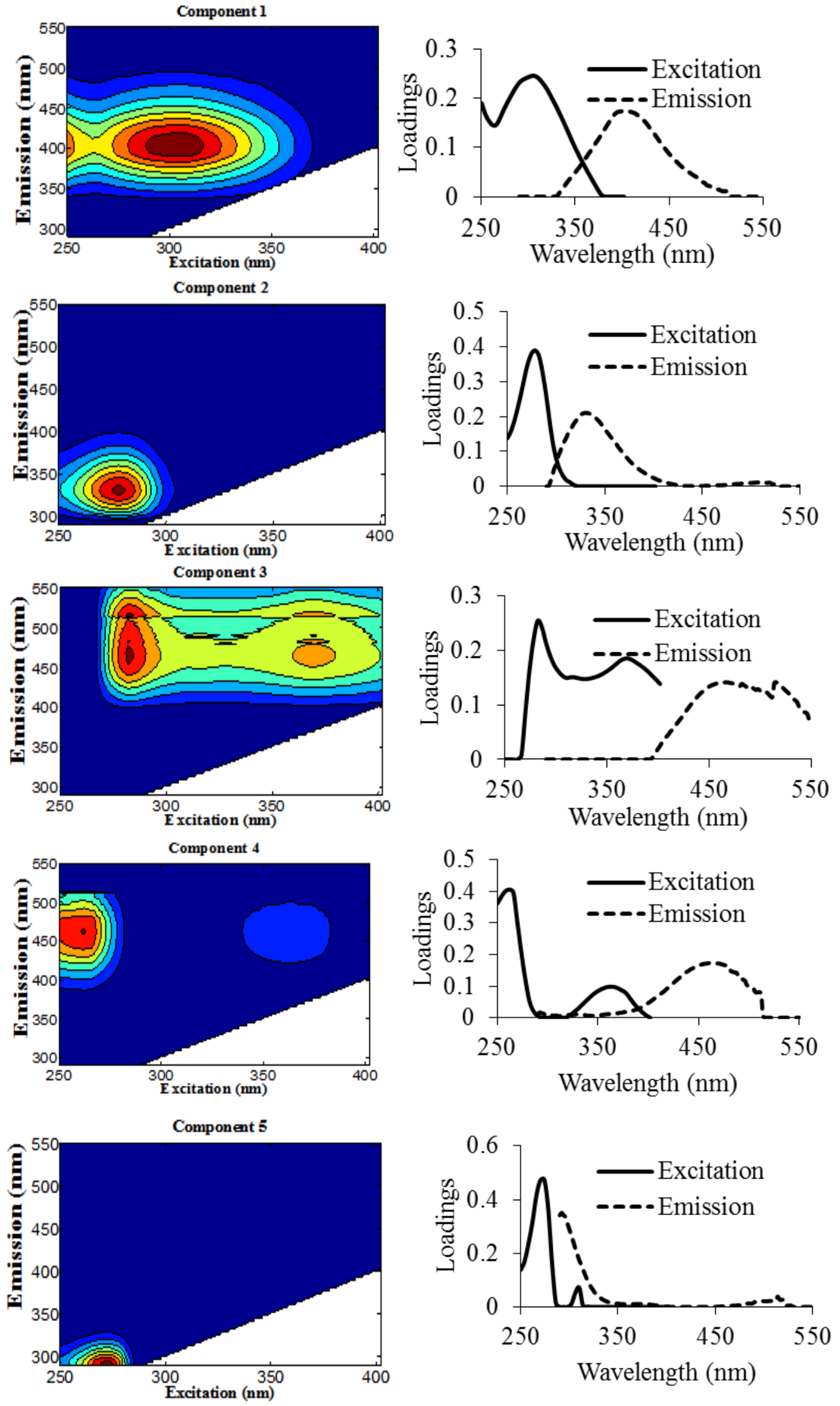

Figure 4. EEM spectra of PARAFAC components and their respective excitation and emission loadings 


\subsection{PARAFAC Components}

The PARAFAC analysis extracted five primary components (C1-C5, Fig. 4). Among these, two (C2 and C5) are protein like components and three $(\mathrm{C} 1, \mathrm{C} 3$ and $\mathrm{C} 4)$ are humic like. $\mathrm{C} 1$ represents marine humic like fluorophore $\mathrm{M}$ with $\mathrm{Ex} / \mathrm{Em}, 306 \mathrm{~nm} / 404 \mathrm{~nm}[29,30]$ observed in various aquatic environments [31-33]. C2 with Ex/Em maxima 278 $\mathrm{nm} / 330 \mathrm{~nm}$ represents the tryptophon protein like fluorphore observed in river and estuarine environments formed from freshly produced phytoplankton and terrestrial organic matter [25,31,34-36]. C3 has two fluorophores, the red shifted UV humic (A) fluorophore at Ex/Em $282 \mathrm{~nm} / 466 \mathrm{~nm}$, and the visible humic (C) fluorophore at Ex/Em, $370 \mathrm{~nm} / 466$ $\mathrm{nm}[34,35]$. It represents the terrestrially derived component observed earlier in north Atlantic and Pacific oceans [9, 25]. $\mathrm{C} 4$ with $\mathrm{Ex} / \mathrm{Em}$ of $262 \mathrm{~nm} / 464 \mathrm{~nm}$ resembles the UV humic like fluorophore (A) observed in both terrestrial and marine waters $[8,25]$. C5 with excitation maxima at $274 \mathrm{~nm}$ and emission maxima at 293 stands for tyrosine protein like [2] fluorophore which has been observed in estuarine and coastal environments and interpreted as an indicator of in situ DOM sources e.g., bacterial degradation of peptides.

\subsection{Variation of Fluorophores in Surface Waters}

The fluorophoric components did not show significant spatial trend from $10 \mathrm{~m}$ to $100 \mathrm{~m}$ isobaths. The fraction of each fluorophoric component was computed as the ratio of the intensity of each component to the total intensity of different components (Fig. 5). Mean contribution of the fluorescence components in surface waters were in the order: $\mathrm{C} 5>\mathrm{C} 2>\mathrm{C} 4>\mathrm{C} 1>\mathrm{C} 3$. The protein like components (tyrosine like, C5 and tryptophan like, C2) were more enriched compared to other components. The tyrosine like component further showed higher contribution from January to April 2011 due to stable water column, enhanced bacterial decay of phytoplankton and of photosynthetically produced organic matter. When local precipitation and fresh water inputs were high (October 2010\&11 and July 2011), B contribution was low as the surface waters were covered by terrestrial derived organic matter, which is rich in high molecular weight humic substances. This is also evidenced by the contribution of UV-humic like flurophoric component (C4) which was high during those months.

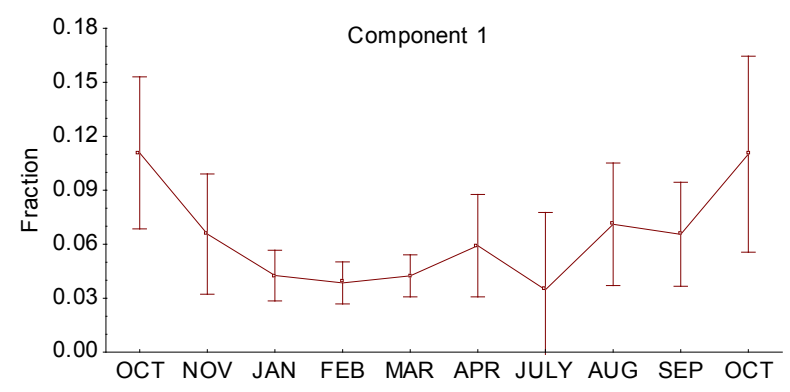

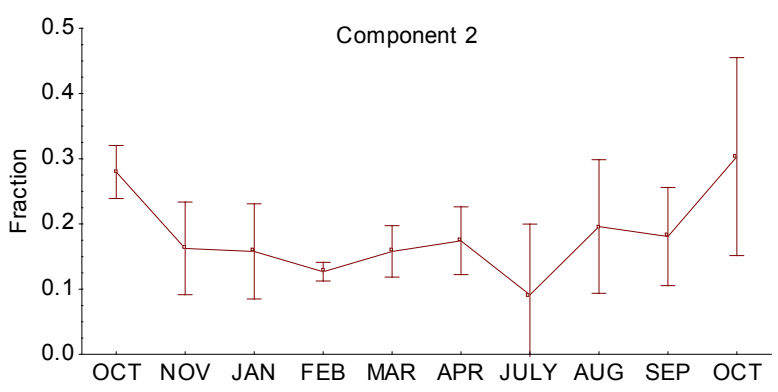
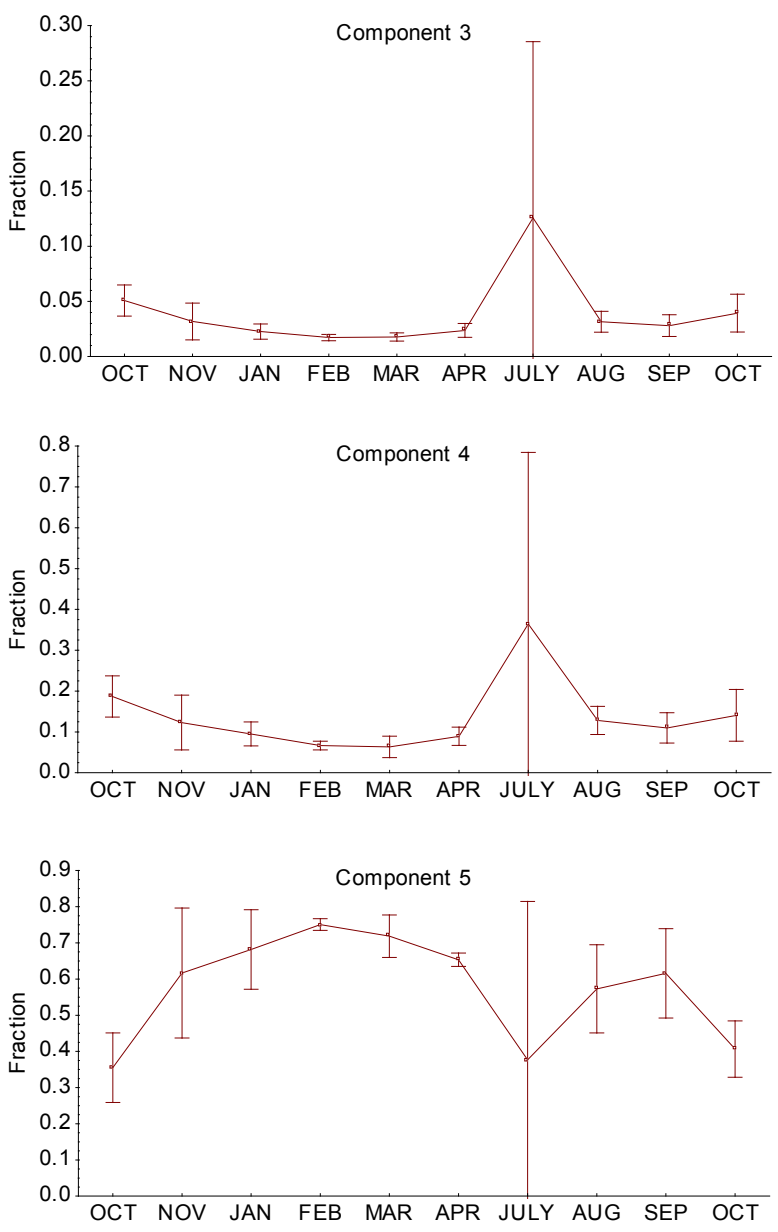

Figure 5. Contribution of fluorophoric components with monthly variation

\subsubsection{Humic Like Fluorescence as Proxy of Phytoplankton Production}

The humic like components $\mathrm{C} 1, \mathrm{C} 3$ and $\mathrm{C} 4$ correlated significantly with salinity $(\mathrm{r}=0.69,0.75$ and $0.79 \mathrm{n}=22$, $\mathrm{p}=0.0004,<0.0001$, and $<0.0001$ for $\mathrm{C} 1, \mathrm{C} 3$ and $\mathrm{C} 4$ respectively) (Fig. 6a) at salinity $<31$. This behaviour is similar to that of coastal waters [e.g., 25,37]. For non-conservative behaviour at higher salinities, photo bleaching plays a major role [37]. Salinity in any range is not correlated to the protein like fluorophores ( $\mathrm{C} 2$ and $\mathrm{C} 5$ ), attributed to their inputs from both the riverine and autochthonous inputs [25]. Chlorophyll a showed significant positive correlation with humic like $\mathrm{C} 3$ and $\mathrm{C} 4$ components 
$(\mathrm{r}=0.69$ and $0.71, \mathrm{p}=0.018$ and 0.014 respectively for $\mathrm{n}=11)$ (Fig. 6b) during premonsoon season (April and May 2011). Except in the case of a eutrophic lake in which $355 / 450$ (ex/em) fluorescence corresponding to C3 was noticed [38], such relationship is rare. Further significant correlation with $\mathrm{C} 4$, which represents A fluorophore which is 5 times more abundant than $\mathrm{C} 3$, which represents $\mathrm{C}$ fluorophore, offers advantage for predicting chl a. The $\mathrm{C}$ and A fluorophores likely owe their origin to bacterial decay of recently formed organic matter introduced by phytoplankton during and after photosynthesis as demonstrated in laboratory cultures [33, $39]$ and in field studies [36, 39,40]. Chl a did not show any relationship with the tyrosine and tryptophan protein like fluorophores despite the fact that the origin of the latter is often attributed to phytoplankton [41]. This is because the formation of protein tryptophan like matter from phytoplankton and its exudates is dependent on whether the species is at the lag, exponential, stationary or decay phases of growth as shown in laboratory axenic cultures [33,41]. In the field environment, the presence of phytoplankton as assemblage further introduces complexity and absence of correlation between chlorophyll and the protein like fluorophores.

\subsection{Vertical Variation of Fluorophores}

The protein like fluorophores $(\mathrm{C} 2, \mathrm{C} 5)$ did not show significant vertical trend. The humic like fluorophores $(\mathrm{C} 1$, C3, C4), however, did show trends (Fig. 7 a,b). Maxima were shown at subsurface in premonsoon and at surface during the monsoon season. The latter can readily be attributed to the surface freshening by the monsoon caused input of humic rich terrestrial flux. The subsurface maxima of the pre-monsoon season are attributed to the twin factors of input by bacterial action and to the fact the FDOM at this level is insulated from photochemical breakdown contrary to surface where illumination that peaks during premonsoon season cause photodegradation [42,43]. Due to quick attenuation with depth of surface irradiation, the photo-induced loss is confined to the surface mixed layer, which during premonsoon season was about 30 meters (Fig. 3a). Below this layer, bacterial metabolism as indicated by lower dissolved oxygen (Fig. 3b), introduces DOM that is particularly rich in chromophores and fluorophores and this process sustains the fluorescence maxima as observed in the Arabian Sea [29], the Sargasso Sea, North Atlantic [44], the eastern Atlantic [45] and North pacific [46].

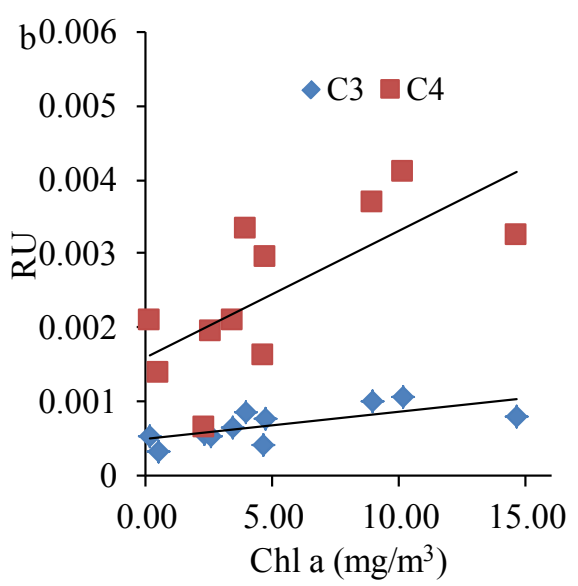

Figure 6. Correlations of Humicfluorophoric components with a) Salinity, b) Chlorophyll a in surface waters
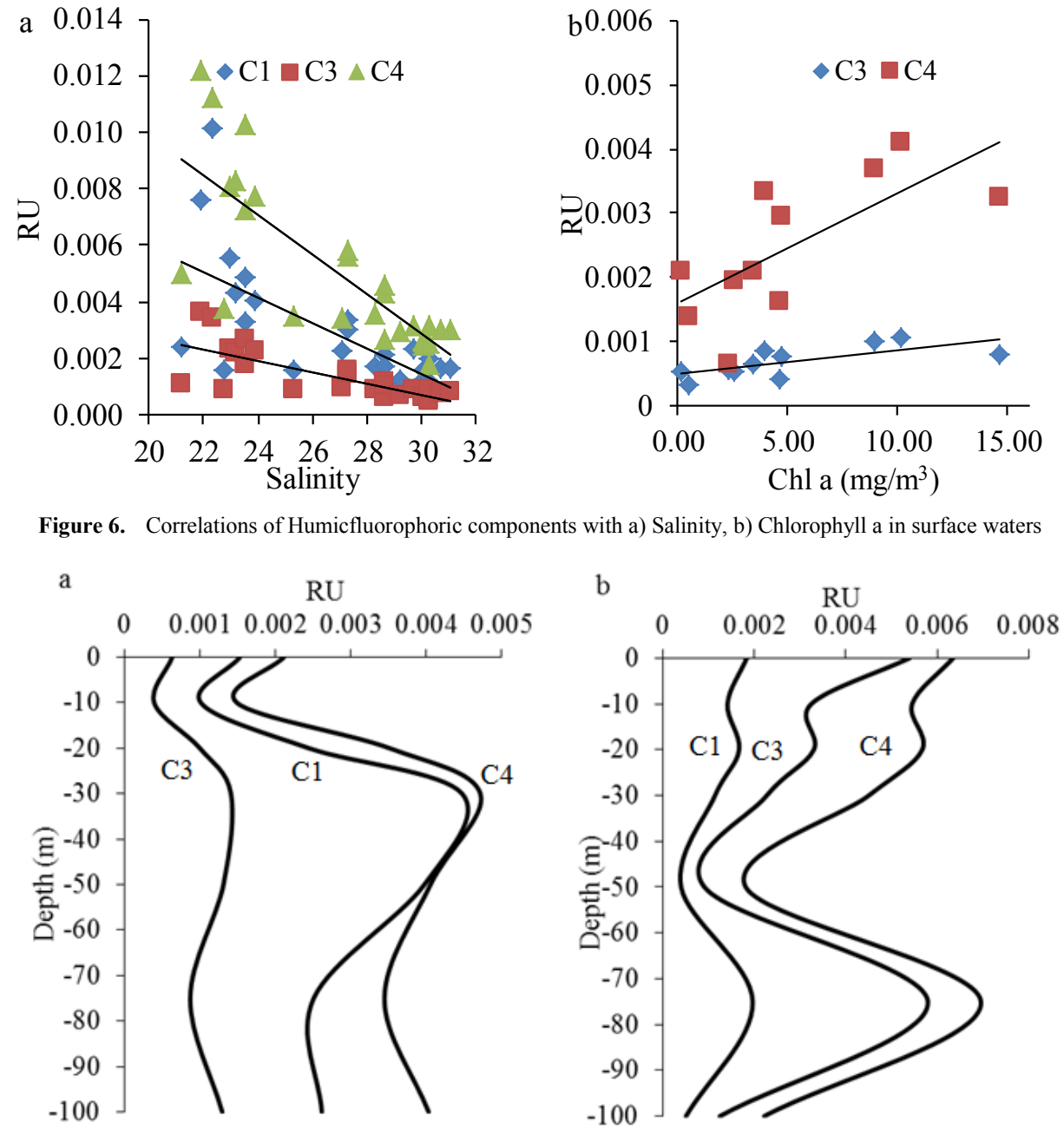

Figure 7. Vertical variation of fluorophoric components during a) Premonsoon season and b) Monsoon season 


\section{Conclusions}

The FDOM in the coastal waters off the western Bay of Bengal where fresh water inputs are little and limited to the monsoon season follows distinct seasonal pattern. During the monsoon season, the humic type fluorescence acted as a proxy for salinity. During the premonsoon season, the tyrosine protein like fluorescence acted as proxy for chlorophyll a (phytoplankton) attributed to bacterial degradation of organic matter recently introduced by the process of photosynthesis.

\section{Acknowledgements}

Authors thank Dr. T. Srinivasa Kumar and Dr. A. A. Lotlikar, Indian National Centre for Ocean Information Services (INCOIS) for advice. Authors thank Dr. SSC Shenoi, Director, INCOIS for financial assistance (INCOIS/093/2007) and are grateful to CSIR for further financial assistance (NSS: Emeritus Scientist; NVHKC: Senior Research Fellow). Financial assistance (to NVHK) for presenting this work at the $17^{\text {th }}$ IHSS conference by Department of Science and Technology (SB/ITS-S/02770/2014-15) is gratefully acknowledged.

\section{REFERENCES}

[1] D.A. Hansell, C.A. Carlson. Biogeochemistry of total organic carbonand nitrogen in the Sargasso Sea: Control by convective overturn, Deep-Sea Res. II. 48 (2001) 1649-1667.

[2] C.A.Stedmon, S. Markager, R. Bro, Tracing dissolved organic matter in aquatic environments using a new approach to fluorescence spectroscopy, Mar.Chem. 82 (2003) 239-254.

[3] P.G. Coble, Marine optical biogeochemistry e the chemistry of ocean color, Chem. Rev. 107 (2007) 402-418.

[4] J.R.Helms, A.Stubbins, J.D.Ritchie, E.C.Minor, D.J.Kieber, K. Mopper, Absorption spectral slopes and slope ratios as indicators of molecular weight,source, and photobleaching of chromophoric dissolved organic matter, Limnol.Oceanogr. 53 (2008) 955-969.

[5] N.A. McEnroe, C.J. Williams, M.A. Xenopoulos, P. Porcal, P.C. Frost, Distinct Optical Chemistry of Dissolved Organic Matter in Urban Pond Ecosystems . PLoS. ONE. 8 (2013) e80334.

[6] K.L. Balcarczyk, J.B. Jones, R.Jaffé, N. Maie, Stream dissolved organic matter bioavailability and composition in watersheds underlain with discontinuous permafrost. Biogeochem. 94 (2009) 255-270.

[7] X.C.Wang, , L. Litz, R.F. Chen, W. Huang, P. Feng, M.A. Altabet, Release of dissolved organic matter duringoxic and anoxic decomposition of salt marsh cordgrass, Mar.Chem. 105 (2007) 309-321.

[8] B.E.W. McKnight, P.K.Westerhoff, P.T. Doran, D.T Andersen, Spectrofluorometric characterization of dissolved organic matter for indication of precursor organic material and aromaticity, Limnol.Oceanogr. 46 (2001) 38-48.

[9] K.R.Murphy, C.A.Stedmon, T.D. Waite, G.M. Ruiz, Distinguishing between terrestrial and autochthonous organic matter sources in marine environment susing fluorescence spectroscopy, Mar.Chem. 108 (2008) 40-58.

[10] A.B.Boehme, G.G. Shellenberger,A. Paytan, Groundwater discharge: potential association with fecal indicator bacteria in the surf zone, Environ. Sci. Technol.38 (2004) 3558-3566.

[11] R.N.Conmy, P.G.Coble,R.F. Chen, G.B. Gardner, Optical properties of colored dissolved organic matter in the Northern Gulf of Mexico, Mar.Chem. 89 (2004) 127-144

[12] E.C. Milbrandt, P.G. Coble, R.N. Conmy, A.J. Martignette, J.J. Siwicke, Evidence for the production of marine fluorescent dissolved organic matter in coastal environments and a possible mechanism for formation and dispersion, Limnol. Oceanogr. 55 (2010) 2037-2051.

[13] J. Para, P.G. Coble, B. Charriere, M. Tedetti, C. Fontana, R. Sempere, Fluorescence and absorption properties of chromophoric dissolved organic matter (CDOM) in coastal surface waters of the northwestern Mediterranean Sea, influence of the Rhône River. Biogeosciences 7 (2010) 4083-4103.

[14] E.J. D’Sa, , J.I. Goes, H. Gomes, C. Mouw, Absorption and fluorescence properties of chromophoric dissolved organic matter of the eastern Bering Sea in the summer with special reference to the influence of a cold pool Biogeosciences, 11 (2014) 3225-3244.

[15] P. Kowalczuk, M. Zablocka, S.Sagan, K. Kulinski, Fluorescence measured in situ as a proxy of CDOM absorption and DOC concentration in the Baltic Sea. Oceanologia, 52 (2010) 431-471. doi:10.5697/oc.52-3.431.

[16] H. Xie, C. Aubry, S. Bélanger, G. Song, The dynamics of absorption coefficients of CDOM and particles in the St. Lawrence estuarine system: Biogeochemical and physical implications, Mar.Chem.128-129 (2012) 44-56.

[17] M.J.Varkey, V.S.N. Murthy A.Suryanarayana, Physicaloceanography of the Bay of Bengal and AndamanSea, Oceanography and Mar. Bio. 34 (1996) 1-70.

[18] P.N.Vinayachandran, S. Mathew, Phytoplankton bloom in the Bay of Bengal and its intensification by cyclones, Geophys. Res. Lettrs. 30 (2003) 1572.

[19] D. Shankar, J.P. McCreary,W. Han, S.R. Shetye, Dynamics of the East India coastal current. 1.Analytic solutions forced by interior Ekman pumping and local alongshore winds, J. Geophys. Res.101 (1996)975-13,991.

[20] K.Grasshoff, M. Ehrhardt, K.Kremling (Eds.), Methods of Seawater Analysis,third ed. VerlagChemie, Weinheim (pub) (1999) $603 \mathrm{pp}$.

[21] D. Carritt, J. Carpenter, Comparison and evaluation of currently employed modifications of the Winklermethod for determining dissolved oxygen in seawater, J. Marine. Res. 24 (1966)286-318.

[22] S.W.Jeffrey, G.F.Humphrey, New spectrophotometric equations for determining chlorophylls $\mathrm{a}, \mathrm{b}, \mathrm{cl}$ and $\mathrm{c} 2$ in higher plants, algae and natural phytoplankton, Biochem.und Physiol. der Pflanzen 167 (1975) 1-194. 
[23] K.R.Murphy,K.Butler, R.M. Spencer, C.A. Stedmon, J. Boehme, G.R. Aiken, Measurement of dissolved organic matter fluorescence in aquatic environments: aninterlaboratory comparison, Environ. Sci. Technol 44 (2010) 9405-9412.

[24] C.A.Stedmon, R.Bro, Characterizing dissolved organic matter fluorescence with parallel factor analysis: a tutorial, Limnol.Oceanogr.: Methods 6 (2008) 1-6.

[25] P.Kowalczuk, M.J. Durako, H. Young, A.E. Kahn, W.J Cooper, M. Gonsior, Characterization of dissolved organic matter fluorescence in the South Atlantic Bight with use of PARAFAC model: inter-annual variability, Mar.Chem. 113 (2009) 182-196.

[26] J. Jian, P.J. Webster, C.D. Hoyos, Large-scale controlson Ganga and Brahmaputra river discharge on intraseasonaland seasonal time-scales,J. Roy. Meteor. Soc.135 (2009)353-370.

[27] V.V. Sarma, V.A. Kumar, Subsurface chlorophyll maxima in the northwestern Bay of Bengal. J. Plank. Res. 13 (1991) 339-352.

[28] P.N. Ganapati, , E.C. Lafond P.V. Bhavanarayana, On the vertical distribution of chemical constituents in the shelf waters off waltair. Proceedings of the Indian Academy of Sciences. 44B (1956) 68.

[29] P.G.Coble, C.E. Del Castillo,B. Avril, Distribution and optical properties of CDOM in the Arabian Sea during the 1995 southwest monsoon. Deep-SeaRes. Part II. 45 (1998) 2195-2223.

[30] E.Parlanti, K. Wörz, L. Geoffroy, M. Lamotte, Dissolved organic matter fluorescence spectroscopy as a tool to estimate biological activity in a coastal zone submitted to anthropogenic inputs, Org.Geochem. 31 (2000) 1765-1781.

[31] X.Luciani, S. Mounier, H.M. Paraquetti, R.Redon, Y. Lucas, A.Bois,L.D. Lacerda, M.Raynaud, M. Ripert, Tracing of dissolved organic matter from theSEPETIBA Bay (Brazil) by PARAFAC analysis of total luminescence matrices, Mar. Environ. Res. 65 (2008) 148-157.

[32] K.R.Murphy, C.A.Stedmon, T.D. Waite, G.M. Ruiz,Distinguishing betweenterrestrial and autochthonous organic matter sources in marine environmentsusing fluorescence spectroscopy, Mar. Chem. 108 (2008) 40-58.

[33] N.V.H.K. Chari, S. Keerthi, N.S. Sarma, S.R. Pandi, G. Chiranjeevulu, R. Kiran, U. Koduru, Fluorescence and absorption characteristics of dissolved organic matter excreted by phytoplankton species of western Bay of Bengal under axenic laboratory condition, J. Exp. Mar. Biol. Ecol. 445 (2013) 148-155.

[34] C.A.Stedmon, S. Markager, Resolving the variability in dissolved organic matter fluorescence in a temperate estuary and its catchment using PARAFAC analysis,
Limnol.Oceanogr 50 (2005) 686-697.

[35] Y.Yamashita, A. Panton, C. Mahaffey, R. Jaffé, Assessing the spatial and temporal variability of dissolved organic matter in Liverpool Bay using excitation-emission matrix fluorescence and parallel factor analysis, Ocean. Dyn. 61 (2011) 569-579.

[36] N.V.H.K.Chari, N.S.Sarma, S.R.Pandi, K.N.Murthy,Seasonal and spatial constraints of fluorophores in the midwestern Bay of Bengal by PARAFAC analysis of excitation emission matrix spectra, Estuar. Coast. Shelf. Sci.100 (2012) 162-171.

[37] Y. Yamashita, R. Jaffé, N. Maie, E. Tanoue, Assessing the dynamics of dissolved organic matter (DOM) in coastal environments by excitation emission matrix fluorescence and parallel factor analysis (EEM-PARAFAC), Limnol. Oceanogr 53 (2008) 1900-1908.

[38] Y.L.Zhang, M.A.Van Dijk, M.L. Liu, G.W. Zhu, B.Q. Qin, The contribution of phytoplankton degradation to chromophoric dissolved organic matter (CDOM) in eutrophic shallow lakes: field and experimental evidence. Water Res. 43 (2009) 4685-4697.

[39] A. Dubnick, J. Barker, M. Sharp, J. Wadham, G. Lis, J. Telling, S. Fitzsimons, M. Jackson, Characterization of dissolved organic matter (DOM) from glacial environments using total fluorescence spectroscopy and parallel factor analysis, Annal. Of Glaciol. 51 (2010) 111-122.

[40] C.Romera-Castillo, H. Sarmento, X.A.Alvarez-Salgado, J.M.Gasol, C.Marrase, Production of chromophoric dissolved organic matter by marine phytoplankton. Limnol. Oceanogr. 55 (2010) 446-454.

[41] J.B.Fellman, K.C. Petrone, P.F. Grierson, Source, biogeochemical cycling, and fluorescence characteristics of dissolved organic matter in an agro-urban estuary, Limnol. Oceanogr. 56 (2011) 243-256

[42] R.F.Chen, J.L.Bada, The fluorescence of dissolved organic matter in seawater, Mar. Chem. 37 (1992) 191-221.

[43] S.Bertilsson, P.Carlsson, W.Granéli, Influence of solar radiation on the availability of dissolved organic matter to bacteria in the Southern Ocean. Deep Sea Research Part II: 51 (2004) 2557-2568

[44] K.Mopper, C.A.Schultz,Fluorescence as a possible tool for studying the nature and water column distribution of DOC components, Mar. Chem. 41 (1993) 229-238.

[45] S.Determann, R.Reuter, R.Willkomm, Fluorescent matter in the eastern Atlantic Ocean. Part 2: vertical profiles and relation to water masses. Deep Sea Res. I 43 (1996) 345-360.

[46] K.Hayase, H. Tsubota, I. Sunada, S. Goda, H. Yamazaki, Vertical distribution of fluorescent organic matter in the North Pacific, Mar. Chem. 25(1988) 373-381. 